amongst men. Prof. Catheart directed the work, assisted by Messrs. Hughes and Chalmers, and in the analysis of the data by Miss Blair and Miss Werner, and their report has now been issued ("The Physique of Man in Industry". Med. Res. Council. I.H.R.B. Report No. 71. H.M. Stationery Office, 1935. 1s. $3 d$. net). It records the physical examina. tion of 13,656 male volunteers aged fourteen years and upwards in fifteen areas in England and Scotland. The total includes 10,593 employed men, 1,328 unemployed men and 1,735 students. The data recorded were height, weight, grip (both hands), pull when standing, and distance of middle finger tip from the ground. The student group had the highest average height and weight, but were inferior in strength to those in manual occupations. The unemployed group was slightly inferior in weight, and definitely inferior in strength, to the employed group. No certain index of physical fitness, industrial or other, was discovered. From the average elbow height (43 in.) of the employed, it is deduced that the comfortable height of a working bench for the average man standing should be about 38 in.

\section{Biological Control of the Mediterranean Fruit Fly}

THE Mediterranean fruit fly (Ceratitis capitata) has, for many years, caused ravages among many kinds of edible fruits in the Hawaiian Islands. The introduction of several species of parasites from Africa and Australia has resulted in a very appreciable reduction in the abundance of the pest in question, but a sufficiently efficient degree of control, from the commercial point of view, has not so far been achieved. We learn from Science Service, Washington, D.C., that a scheme has been put in hand which involves further application of biological control methods. In order to carry out the project, the Hawaiian Planters' Association is sending two of its entomologists, along with others from the Department of Agriculture, to Africa with the object of searching for suitable parasites. Other entomologists are proceeding to Brazil with the same aim in view. The whole project is being administered by the U.S. Bureau of Entomology in conjunction with the leading local organisations concerned in Hawaii. The Hawaiian Islands are famous as being the territory where some of the most successful examples of the biological method of pest control have been achieved. The plan of campaign against the fruit fly is expected, if successful, to lead to great benefits to the small farmers of the territory by increasing the supply of fruits that grow so luxuriously in those islands.

\section{New System for Nature Recording}

AFTER much discussion, extending over two quarterly meetings, the council of the British Empire Naturalists' Association has agreed to form a special section to deal with field natural history records. A properly spaced system of observers is to be built up all over Great Britain, and eventually a committee of experts will be formed to decide upon the problems to be tackled, and the methods to be adopted. Plans are at present being made for a conference of branch secretaries in London next April. For some ten years, the British Empire Naturalists' Association has worked a system of publishing in its quarterly journal, Country-Side, bird, plant and insect records of seasonal and statistical interest, grouped in the various counties. Not only was this incomplete, in that records were more quickly forthcoming from southern areas richest in resident naturalists, and other northern areas were neglected, but also in flora especially no complete review could be made owing to the necessity of finding room for other matters in the journal. The new scheme will be welcomed by historians of field natural history, who often have to go through masses of local and national publications for scattered field records of varying value.

\section{A New Natural History Magazine}

A NEW German periodical, edited by A. Benninghoff, K. Beurlen, K. Hildebrandt and K. L. Wolf, offering a variety and standard of contributions which ought to commend it to many readers, has recently appeared. The title, Zeitschrift für die gesamte Naturwissenschaft, suggests the breadth of its objective, the scope of which is extended by the inclusion of Nature philosophy and the history of Nature knowledge and medicine. The articles of the first issue (April) are not over-long-about fifteen pages - a short summary precedes each, and the matter, while avoiding too technical treatment, makes a serious contribution to the subjects discussed. K. Hildebrandt writes upon "Positivismus und Natur", and other major articles deal with "Morphologie und Erdgeschichte", "Bedeutung und Aufgabe geologischer Forschung", "Subjektbezogenen Nomenklatur in der Biologie", "Warum studieren wir Biologie?", to which the final answer is "Wir studieren Biologie, weil wir müssen". A variety of subjects are discussed in short contributions, and there are seven signed reviews of books.

\section{Use of the Astrolabe}

AlтнобGH the astrolabe has found some support among surveyors, it has not been widely used by British astronomers. An extensive account in English of the practical use of the modern astrolabe has recently been published by $\mathrm{Mme}$. Chandon and M. Gougenheim in the Hydrographic Review (12, No. 1). This account contains full details of the working and practical operation of various modifications of the astrolabe, and should be studied by all who are interested in the accurate determination of position. It may be hoped that this paper will stimulate astronomers to devise a means of eliminating personal equation from the astrolabe, so that the instrument may eventually compete with the transit circle in the accurate determination of longitude.

\section{Pathological Investigations at Edinburgh}

IN the annual report for 1934 of the Laboratory of the Royal College of Physicians of Edinburgh, by the curator, Sir Robert Phillips, an account is given of the research and other activities. Much work has 
been done, particularly on the pathology of the mamma, by Miss Dawson, and about 1,000 reports on tumour growths were issued; the sections made, together with the material from which they are derived, are preserved and indexed for future reference and research. The death rates of Great Britain and Sweden and the spread of infectious diseases have also been investigated statistically. More than 15,000 examinations of specimens for medical men were carried out.

Society for the Study of Alchemy and Early Chemistry

A Society for the Study of Alchemy and Early Chemistry has been founded in London. It is intended to place the study of alchemy and early chemistry on a broad basis, and for this reason the Council of the Society is desirous of securing the co-operation of scholars in various countries who will contribute to the interests of the Society. It is proposed to hold regular meetings, beginning early in 1936, at which papers will be read and discussed, and to publish a journal in which accounts of the papers will ke given as well as special articles, written contributions by members of the Society and reviews of books. The following council has been elected: Prof. J. R. Partington (chairman), Dr. F. Sherwood Taylor (Editor of the Journal), Gerard Heym (Hon. Secretary), K. de B. Codrington, L. F. Gilbert, Prof. S. R. K. Glanville, Sir Richard Gregory, Dr. E. J. Holmyard, Dr. D. McKie, Dr. L. W. G. Malcolm, Dr. Stephen Miall. Further information can be obtained from the Hon. Secretary, Society for the Study of Alchemy and Early Chemistry, 8 Bream's Buildings, Fetter Lane, London, E.C.4.

\section{International Geological Congress, 1937}

THE organisation committee of the seventeenth session of the International Geological Congress, which will meet in Moscow in 1937, has issued a second circular outlining the scope of the various subjects proposed for discussion. In connexion with the problems associated with the geology of petroleum and coal, it is hoped to make an estimate of the oil reserves of the world and to review the coal resources of the U.S.S.R. and other countries. A discussion of the stratigraphy, igneous cycles, tectonics and mineral deposits of the Pre-Cambrian is proposed. The stratigraphical limits of the Permian System, at present a source of widespread controversy, again comes up for consideration. An attempt is to be made to correlate tectonics, magmatic evolution, ore deposits and geochemistry, and as a further theme a review of the data bearing on these problems with special reference to Asia is proposed. Another geochemical problem is that of the occurrences of rare elements. Geophysical subjects to be discussed include measurement of geological time ; isostasy and anomalies of gravity; terrestrial magnetism; and seismology. Finally, it is hoped that reports will be presented on the history of the various branches of geology. Further particulars may be obtained from the General Secretary, Dr. A. E. Fersman, Sretenka 8, Moscow 10.

\section{Announcements}

Dr. H. S. GASSEN, professor of physiology at Cornell University, New York, has been nominated director of the Rockefeller Institute in succession to Dr. Simon Flexner.

Prof. Yas Kuno, until recently of the Japanese Medical College, Mukden, South Manchuria, and now of the Institute of Physiology, Kyoto Imperial University, Japan, has been appointed a member of the Permanent International Committee of the Physiological Congresses. This is the first time that a representative of Far Eastern physiology has been appointed to the Committee. Prof. Kuno was a pupil of the late Prof. E. H. Starling at University College, London, and is a member of the Physiological Society, Great Britain. He has done very important work on perspiration and body temperature, and has written an excellent book on the subject.

Mr. M. C. LAmb, principal of the Leathersellers' Technical College, will retire from his present position at the termination of the current session, having then attained the age of sixty years. Mr. Lamb has been associated with the College from the time of its opening in 1909, and has had forty years' experience in the teaching of leather technology, having been appointed a demonstrator in the Leather Department of the University of Leeds so far back as 1895. During the period of his occupation of the principalship, the College has been progressively successful, and is now regarded as the most efficient and best equipped of its kind in the world, attracting students from every centre where leather is produced.

Among the awards for 1935 made by the Royal Horticultural Society are the following: Victoria Medal of Honour, Sir Daniel Hall, for his scientific work in connexion with horticulture; Veitch Memorial Medals, Dr. A. D. Cotton, for his services to horticulture, and Prof. E. J. Salisbury, for his book "The Living Garden"; Loder Rhododendron Cup, Mr. A. Rehder, of the Arnold Arboretum, U.S.A., for his work on the genus Rhododendron.

A Discussion on "Probability" will be held by the London Mathematical Society on January 16, at 5 p.m., in the rooms of the Royal Astronomical Society, Burlington House, W.1. The following have promised to take part: Prof. H. Levy, Sir Arthur Eddington, Dr. P. Dienes, Prof. R. A. Fisher, Dr. Harold Jeffreys, Prof. J. B. S. Haldane.

Is ceference to the article on the annual Congress and Exhibition of the British Institute of Radiology in Nature of December 14, p. 960, Dr. J. Read informs us that the first continuously evacuated tube constructed by Lauritzen worked intermittently at $750 \mathrm{k} . \mathrm{v} .$, not $600 \mathrm{k} . \mathrm{v}$. ; also that the Soiland Clinic tube worked at $550 \mathrm{k} . \mathrm{v}$., not $100 \mathrm{k} . \mathrm{v}$. , and that the Clinic has now installed three $200 \mathrm{k} . \mathrm{v}$. constant potential Latour circuits in cascade in place of the cascade transformers. 